The National Bureau of Standards ${ }^{1}$ was established by an act of Congress March 3, 1901. The Bureau's overall goal is to strengthen and advance the Nation's science and technology and facilitate their effective application for public benefit. To this end, the Bureau conducts research and provides: (1) a basis for the Nation's physical measurement system, (2) scientific and technological services for industry and government, (3) a technical basis for equity in trade, and (4) technical services to promote public safety. The Bureau consists of the Institute for Basic Standards, the Institute for Materials Research, the Institute for Applied Technology, the Center for Computer Sciences and Technology, and the Office for Information Programs.

THE INSTITUTE FOR BASIC STANDARDS provides the central basis within the United States of a complete and consistent system of physical measurement; coordinates that system with measurement systems of other nations; and furnishes essential services leading to accurate and uniform physical measurements throughout the Nation's scientific community, industry, and commerce. The Institute consists of a Center for Radiation Research, an Office of Measurement Services and the following divisions:

Applied Mathematics-Electricity-Heat-Mechanics-Optical Physics-Linac Radiation ${ }^{2}$ - Nuclear Radiation ${ }^{2}$ - Applied Radiation ${ }^{2}$ - Quantum Electronics ${ }^{3}$ Electromagnetics ${ }^{3}$ - Time and Frequency ${ }^{3}$-Laboratory Astrophysics ${ }^{3}$-Cryogenics ${ }^{3}$.

THE INSTITUTE FOR MATERIALS RESEARCH conducts materials research leading to improved methods of measurement, standards, and data on the properties of well-characterized materials needed by industry, commerce, educational institutions, and Government; provides advisory and research services to other Government agencies; and develops, produces, and distributes standard reference materials. The Institute consists of the Office of Standard Reference Materials and the following divisions:

Analytical Chemistry-Polymers-Metallurgy-Inorganic Materials-Reactor Radiation-Physical Chemistry.

THE INSTITUTE FOR APPLIED TECHNOLOGY provides technical services to promote the use of available technology and to facilitate technological innovation in industry and Government; cooperates with public and private organizations leading to the development of technological standards (including mandatory safety standards), codes and methods of test; and provides technical advice and services to Government agencies upon request. The Institute also monitors NBS engineering standards activities and provides liaison between NBS and national and international engineering standards bodies. The Institute consists of the following divisions and offices:

Engineering Standards Services-Weights and Measures-Invention and Innovation-Product Evaluation Technology-Building Research-Electronic Technology-Technical Analysis-Measurement Engineering-Office of Fire Programs.

THE CENTER FOR COMPUTER SCIENCES AND TECHNOLOGY conducts research and provides technical services designed to aid Government agencies in improving cost effectiveness in the conduct of their programs through the selection, acquisition, and effective utilization of automatic data processing equipment; and serves as the principal focus within the executive branch for the development of Federal standards for automatic data processing equipment, techniques, and computer languages. The Center consists of the following offices and divisions:

Information Processing Standards-Computer Information-Computer Services - Systems Development-Information Processing Technology.

THE OFFICE FOR INFORMATION PROGRAMS promotes optimum dissemination and accessibility of scientific information generated within NBS and other agencies of the Federal Government; promotes the development of the National Standard Reference Data System and a system of information analysis centers dealing with the broader aspects of the National Measurement System; provides appropriate services to ensure that the NBS staff has optimum accessibility to the scientific information of the world, and directs the public information activities of the Bureau. The Office consists of the following organizational units:

Office of Standard Reference Data-Office of Technical Information and Publications-Library-Office of International Relations.

\footnotetext{
${ }_{1}$ Headquarters and Laboratories at Gaithersburg, Maryland, unless otherwise noted; mailing address Washington, D.C. 20234.

2 Part of the Center for Radiation Research.

s Located at Boulder, Colorado 80302.
} 


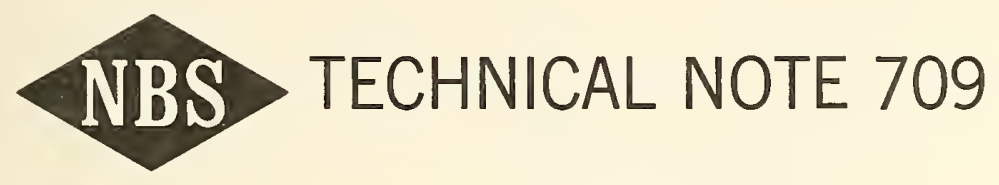

\author{
ISSUED FEBRUARY 1972
}

Nat. Bur. Stand. (U.S.), Tech. Nate 709, 15 pages (Feb。 1972)

CODEN: NBTNAE

\title{
An X-Ray Diffraction Method for Determining the Amount of Austenite in an Austenite-Ferrite Mixture
}

\author{
C. J. Bechtoldt \\ Institute for Materials Research \\ National Bureau of Standards \\ Washington, D.C. 20234
}

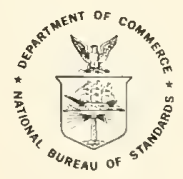

NBS Technical Notes are designed to supplement the Bureau's regular publications program. They provide a means for making available scientific data that are of transient or limited interest. Technical Notes may be listed or referred to in the open literature.

For sale by the Superintendent of Documents, U.S. Government Printing Office,Washington, D.C., 20402. (Order by SD Catalog No. C 13.46:709). Price 30 cents. 

CONTENTS

Page

Introduction . . . . . . . . . . . . . . . . 2

Theory • • • • . • . • . • . • • . • . 2

Measurement Method and Application . . . . . . . . . . 4

References . . . . . . . . . . . . . . . 7

Appendix . . . . . . . . . . . . . . . . . . 7

Table I . . . . . . . . . . . . . . . 8 

An X-ray Diffraction Method for Determining the Amount of Austenite in an Austenite-Ferrite Mixture

\author{
by \\ C. J. Bechtoldt \\ Metallurgy Division \\ Institute for Materials Research \\ National Bureau of Standards \\ Washington, D. C. 20234
}

A method for determining the relative phase volume of austenite in an austenite-ferrite mixture is described in detail. Results obtained by applying this method to an austenitic-ferritic stainless steel composite material are presented. The method can be extended to other multi-phase materials.

Keywords: Austenite; computer; ferrite; phase measurement; quantitative analysis; retained austenite and x-ray diffraction. 


\section{INTRODUCTION}

In the characterization of alloys it is often important to determine the volume fraction of certain phases. In the case of ferrous alloys it is necessary to measure the amount of austenite retained after thermomechanical processing since it will affect important mechanical properties. Several different techniques have appeared in the literature (see references in (1) and (2)) for determining the relative amount of austenite, employing x-ray diffraction methods. This note will discuss in detail the method in use in our laboratory, which differs in some respect from these other techniques. Principally, integrated intensity measurements from as many resolved, individual, diffraction lines as possible are combined to determine a best value for the volume fraction of austenite. Computer processing permits rapid collection of data and calculation of results. An example of the application of this method to a recent NBS standard reference material will be given.

\section{THEORY}

The theory concerned with the calculation of the volume fraction of a phase in a mixture using a diffractometer has been summarized and discussed by Ogilvie(2). That method assumes, as is done here, a random orientation of the diffracting crystallites. Modifications of the method to account for preferred orientation in, for example, rolled material, have been proposed(3) and will not be considered here. 
The integrated intensity of a reflection ( $h k l)$ is given by:

$$
P_{h k l}=K \cdot F^{2} \cdot T \cdot L \cdot p \cdot j \cdot A \cdot V / V_{C}^{2}
$$

where

$$
\begin{aligned}
& K= \text { scale factor (constant for a given experiment) } \\
& f= \text { scattering factor } \\
& F=\left.f \cdot S \text {, the structure factor (and } F^{2} \equiv F^{*}\right) \\
& T= e^{-2 B / 4 d^{2}} \text {, the temperature factor, where } B \text { is a constant and } \\
& d \text { the interplanar spacing. } \\
& S= \text { symmetry factor with } S=2 \text { (body-centered-cubic) } \\
& \qquad S=4 \text { (face centered cubic) } \\
& L \cdot P=\left(1+\cos ^{2} 2 \theta\right) /\left(\sin ^{2} \theta \cdot \cos \theta\right) \text {, Lorentz polarization for } \\
& \text { powder specimen } \\
& j= \text { multiplicity factor } \\
& A= \text { absorption factor (nearly constant for thick specimens) } \\
& V= \text { volume fraction of the phase of interest, and } \\
& V_{C}= \text { unit cell volume. }
\end{aligned}
$$

The known terms are collected into a quantity $R^{\text {hk } 1}$ so that eq (1) can be written

$$
P_{h k 1}=K \cdot R^{h k 1} \cdot V
$$

where

$$
R^{h k 1} \equiv F^{2} \cdot T \cdot L \cdot P \cdot j \cdot A / v_{C}^{2}
$$

Forming the ratio for two phases from eq (2), we have 


$$
\frac{P_{1}^{h k l}}{P_{2}^{h \cdot k} l}=\frac{K R_{1}^{h k l} V_{1}}{K R_{2}^{h \cdot k^{\prime} T} \dot{V}_{2}}
$$

and if $v_{1}+v_{2}=1$ (two phase material) then

$$
v_{2}=\frac{R_{1}^{h k 1} P_{2}^{h^{\prime} k^{\prime} l^{\prime}}}{R_{2}^{h^{\prime} k^{\prime} l^{\prime}} P_{1}^{h k 1}+R_{1}^{h k 1} P_{2}^{h^{\prime} k^{\prime} l^{\prime}}}
$$

or

$$
v_{2}=\frac{\left(R_{1} / P_{1}\right)^{h k 1}}{\left(R_{1} / P_{1}\right)^{h k T}+\left(R_{2} / P_{2}\right)^{h \cdot k ' T !}} .
$$

Lettáng $I=R / P$ and averaging over all reflections in a phase, eqn. 5 becomes

$$
\bar{V}_{2}=\frac{\bar{I}_{1}}{\bar{I}_{1}+\bar{I}_{2}}
$$

and the standard deviation is given by

$$
s_{V_{2}}=\bar{V}_{2}\left(1-\bar{V}_{2}\right)\left[\left(s_{I_{1}} / \bar{I}_{1}\right)^{2}+\left(s_{I_{2}} / \bar{I}_{2}\right)^{2}\right]^{1 / 2} .
$$

The method for determining the average volume fraction $\bar{V}_{2}$ from calculated values $R_{i}$ and measured values $P_{i}$ was programmed for computer calculation and is described in the next section.

MEASUREMENT METHOD AND APPLICATION

The experimental conditions used with the application of the method to an austenitic-ferritic stainless steel composite will be described. Appropriate adjustments in, for example, radiation, stepping intervals and so forth, can be made for studies of other materials. In the present instance cobalt radiation (iron filtered) was obtained from a constant potential $x$-ray generator operated at $35 \mathrm{kV}$. The step-scanning diffractometer used $\mathrm{a} 1^{\circ}$ scattering slit and a .024 inch receiving slit. Counting 
periods of 50 to $100 \mathrm{~s}$ were chosen, with a $2 \Theta$ step interval of 0.05 deg (this choice is determined in part by the sharpness of the peaks). For the purpose of minimizing the effect of grain size, the specimen was rotated in its plane at $117.8 \mathrm{rpm}$ during measurement.

The scaler output was recorded directly on punched paper tape to facilitate loading the data into a digital (time-shared) computer. Other input information, such as the interval for background corrections, the interval over which the peaks were integrated, appropriate $\mathrm{hkl}$, multiplicity, and symmetry factor were supplied from a previously loaded control file. Integration of the diffraction lines was accomplished using Simpson's rule. The diffraction line center-of-gravity along the $2 \Theta$ axis was also determined and used to specify the angular position of the line. The computer program (described in the Appendix) then calculated the d-spacing, Lorentz polarization factor (with or without monochromator), unit ce 11 volume, and temperature factor. The scattering factor was calculated from the relation (4):

$$
f_{h k 1}=A \exp \left(-B / 4 d^{2}\right)+C \exp \left(-D / 4 d^{2}\right)+E
$$

where $A, B, C, D, E$ are constants (see Appendix). A correction was made to these calculated values in order to account for anomalous scattering. 
The computer program provides for a linear correction of background intensity. The theoretical relative intensity ( $R$ in eq 2 ) of the principal diffraction lines of each phase is calculated and printed out together with the observed integrated intensity and relative integrated intensity for comparison. As a further check the multiplicity, temperature factor, scattering factor correction, Lorentz polarization factor, $2 \ominus$ angle, d-spacing and average lattice constant are also printed out. To minimize systematic biases in the final calculated phase volume fraction, the calculations are done for as large a number of planes as possible and averaged together. In the austenite-ferrite example, presented next, this involved 5 planes for the fcc phase and 4 planes for the bcc phase.

The output obtained from measurements on an austenitic-ferritic stainless steel composite specimen is shown in table $I$. The average volume percent austenite present is shown followed by individual values obtained from pairs of diffraction lines. The scatter shown indicates the need for caution in basing phase volume determinations on only a few observed diffraction lines, particularly at low relative values.

This program can be used with slight modification for other phases with simple structure and can be extended to more complicated structures with the introduction of the appropriate equations for the symmetry factor. A modification of this program has also been used to study preferred orientation resulting from the directional growth of crystals on electrodeposited plates in various plating solutions. 


\section{REFERENCES}

[1] Beu, K. E., Austenite Retained in Hardened Steels: Quantitative Determination by X-Ray Diffraction Techniques", in the Encyclopedia of X-Rays and Gamma Rays, George L. Clark, ed., Reinhold Publishing Corp., New York, pp. $71-77$ (1963).

[2] Ogilvie, R. E., Retained Austenite by X-Rays, Norelco Reporter, p. 60-63 (1959).

[3] Morris, P. R., Measurement of Retained Austenite in PrecipitationHardening Stainless Steels, Trans. AIME, 239, pp. 1586-1589 (1967).

[4] Forsyth, J. B. and Wells, M., On an Analytic Approximation to the Atomic Scattering Factor, Acta, Cryst. 12, pp. 412-515 (1959). APPENDIX

The computer program listed below is written in the BASIC language and should execute on most time-shared computer terminals accepting a BASIC language, except perhaps for minor changes in input and output statements. This program has executed on four different systems available in our laboratory.

Because of size limitations this program initially consisted of three programs but they were recently combined. It should be possible to subdivide again if necessary for a particular computer system.

The program permits greater details to be printed at execution time or listed after execution. This was incorporated to "shake down" the original program, facilitate transfer between time-sharing services, and permit inspection of data used for background correction and data over which the peaks were to be integrated.

A punched paper tape of this program can be provided on request to the author. 
Table I. Computer output showing calculated and observed integrated diffraction line intensities, and relative phase volume in a study of an austenitic-ferritic stairiless steel composite.

XBASIC B

RUN

DEFINE FILE

$1=$ C ONTRL

DEF INE FILE

$2=\mathrm{HJL} 4$

SPEC IMEN DES IGNAT ION--! HICHO JL4

DETAILED PRINTOUT DESIRED? ENTER $Y$ IF YES AND $N$ IF NO! $N$ FOR LP, ENTER 1 IF MONOCHROMATOR., 2 IF NOT. ! 2 ANOMALOUS SCAT FACT . CORRECTION, ENTER O IF NONE DESIRED. ! 2.5 TEMPERATURE CONSTANT $R=.4$

AUSTENITE

\begin{tabular}{|c|c|c|c|c|c|c|}
\hline PLANE & M & SCAT $\cdot F$ & TEMP $\cdot F$ & LP & $F$ & $D-S P A C I N G$ \\
\hline 111 & 8 & $16 \cdot 36$ & .954 & 8.27 & 63.93 & 2.072 \\
\hline 200 & 6 & $15 \cdot 20$ & .940 & $5 \cdot 82$ & $58 \cdot 93$ & $1 \cdot 797$ \\
\hline 220 & 12 & $11 \cdot 82$ & .883 & $2 \cdot 83$ & $44 \cdot 42$ & $1 \cdot 268$ \\
\hline 311 & 24 & $10 \cdot 10$ & .844 & $2 \cdot 94$ & $37 \cdot 12$ & 1.084 \\
\hline 222 & 8 & 9.61 & .830 & $3 \cdot 30$ & 35.03 & 1.037 \\
\hline
\end{tabular}

PLANE

111

200

220

311

222
TWO-THETA

$51 \cdot 190$

59.771

89.854

111.325

119.436

RELATIUE
CALC I I
$100 \cdot 00$
$44 \cdot 84$
$24 \cdot 78$
$35 \cdot 97$
$11 \cdot 98$

RELATIUE
OBSERVED I
$100 \cdot 00$
$32 \cdot 68$
$25 \cdot 75$
$33 \cdot 56$
$10 \cdot 82$

OBSERVED I NTEGRATED I

$156 \cdot 60$

$51 \cdot 18$

$40 \cdot 33$

$52 \cdot 55$

16.94

LATTICE CONSTANT $=3 \cdot 591$ 


$\begin{array}{lrllllc}\text { PLANE } & M & \text { SCAT } \cdot F & \text { TEMP } \cdot F & \text { LP } & \text { F } & \text { D-SPACING } \\ 110 & 12 & 16.18 & .952 & 7.81 & 31.57 & 2.024 \\ 200 & 6 & 13.10 & .907 & 3.44 & 24.96 & 1.434 \\ 211 & 24 & 10.96 & .864 & 2.73 & 20.38 & 1.172 \\ 220 & 12 & 9.39 & .824 & 3.56 & 17.03 & 1.015\end{array}$

$\begin{array}{lcccc}\text { PLANE } & \text { TWO-THETA } & \text { RELATIVE } & \text { RELATIUE } & \text { OBSERUED } \\ 110 & \text { CALC I } & \text { OBSERUED } & \text { INTEGRATED I } \\ 200 & 52.493 & 100.00 & 100.00 & 4558.26 \\ 211 & 77.254 & 13.78 & 14.73 & 671.23 \\ 220 & 99.628 & 29.12 & 31.52 & 1436.58 \\ & 123.684 & 13.28 & 13.80 & 629.12\end{array}$

LATTICE CONSTANT $=2 \cdot 868$

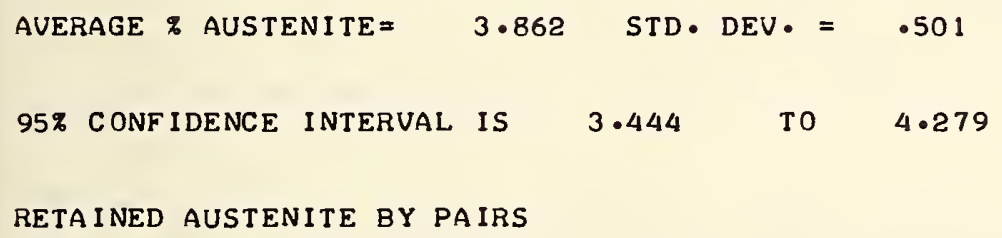

PLANES

$\begin{array}{ccc}\text { AUSTENITE } & \text { FERRITE } & \text { AUSTENITE } \\ 111 & 110 & 4.37 \\ 200 & 110 & 3.22 \\ 220 & 110 & 4.53 \\ 311 & 110 & 4.09 \\ 222 & 110 & 3.96 \\ 111 & 200 & 4.10 \\ 200 & 200 & 3.02 \\ 220 & 200 & 4.25 \\ 311 & 200 & 3.83 \\ 222 & 200 & 3.72 \\ 111 & 211 & 4.05 \\ 200 & 211 & 2.99 \\ 220 & 211 & 4.20 \\ 311 & 211 & 3.79 \\ 222 & 211 & 3.67 \\ 111 & 220 & 4.21 \\ 200 & 220 & 3.11 \\ 220 & 220 & 4.37 \\ 311 & 220 & 3.94 \\ 222 & 220 & 3.82\end{array}$


100 FILES *, * PERMITS DESIGNATION OF CONTROL AND DATA FILES AT RUN TIME

110 FMT $14, \mathrm{I} 6, \mathrm{~F} 9 \cdot 2, \mathrm{~F} 11.3, \mathrm{~F} 12 \cdot 2, \mathrm{~F} 12 \cdot 2, \mathrm{~F} 12 \cdot 3$

$120 \mathrm{DIM} X(600), Y(500), Z(500), H(2,5), C(2,5), P(2,5), O(2,5), U(2,5), M(2,5)$

$130 \mathrm{DIM} \mathrm{B}(2,5), N(2), A(2), F(9), G(9), A \Phi(2), T(2,5), D(2), J(2)$

140 FMT //

150 FMT I $4, F 15 \cdot 3, F 12 \cdot 2, F 12,2, F 14,2, F 12 \cdot 3$

160 FMT "LATTICE CONSTANT $="$ F $6 \cdot 3, / / 1$

170 FMT "AVERAGE \% AUSTENITE=",F9.3," STD・ DEV• =",F7•3, //

190 FMT "95\% CONFIDENCE INTERUAL IS",F9.3,"

200 FMT "RETAINED AUSTENITE BY PAIRS"//"

210 FMT "AUSTENITE FERRITE \% AUSTENITE"

PLANES"

220 FMT I6,I10,F12.2

230 FMT "TEMPERATURE C ONSTANT $\mathrm{B}=$ ", F4.1

240 FMT I $8,15,15$, I5, I 5

250. READ 1, N(1), N(2), $M 1, M 2, M 3, W 1, P 1, T 9, A(1), A(2), A \Phi(1), A \Phi(2)$

260 PRINT, 140

270 PRINT"SPEC INEN DES IGNAT I ON--";

280 INPUT TS 'COMPUTER CALLS FOR SPECIMEN DESIGNATAON'

290 PR.INT

300 PRINT "DETAILED PRINTOUT DESIRED? ENTER Y IF YES AND N IF NO";

310 INPUT T\$

320 PR INT

330 PRINT"FOR LP, ENTER 1 IF MONCH•, 2 IF NOT• ";

340 INPUT N1

350 PRINT

360 PRINT"ANOMALOUS SCAT • FACT - CORRECTION, ENTER O IF NONE DESIRED.

370 INPUT S9

380 PRINT

390 READ \#2,Q9

400 * AT THIS POINT PROGRAM READS IN SCALER FILE AND SORTS DATA FOR

410 *BACKGROUND CORRECTION, AUSTENITE PEAKS, AND FERRITE PEAKS.

420 *CONTROL IS EXERC ISED FROM THE CONTROL FILE WHICH IS AMENDED FOR

430 *EACH RUN IF, NECESSARY. ALL ANGULAR DATA IS IN TERMS OF

440 *TWO-THETA TIMES 1000 .

450 READ $1, A, S, T, A 3$

$460 * A=S T A R T$ ING ANGLE ${ }^{-}$AND A3=ENDING ANGLE OF DIFFRACTOMETER RUN

$470 * S=S T E P P I N G$ ANGLE AND T=COUNT ING TIME INTERUAL.

$480 \quad A=A-S$

490 READ $1, \mathrm{~N}, \mathrm{~A} 1, \mathrm{AZ}$

$500 * N=S O R T$ ING INSTRUCT I ONS, 1--BACKGROUND, 2--AUSTENITE PEAK

$510 * 3--F E R R I T E$ PEAK: A1 AND A2 STARTING ANGLE AND ENDING ANGLE OF

520 *THE SCAN OF INTEREST.

$530 \quad A=A+S$

540 READ 2 , B

$550 \quad B=B+Q 9$

560 IF $A<>A 1$ THEN 530

570 ON N GOTO $620,740,870$

580 IF T $\$=" N "$ THEN 600

590 PRINT, 240, A:M1;M2;M3

600 IF $A<A 3$ THEN 490

610 GOTO 1030

$620 \quad \mathrm{M} 1=\mathrm{M} 1+1$

$630 X(M 1)=A 1$

$640 \quad M_{1}=M_{1}+1$

$650 \times\left(M_{1}\right)=B$

660 IF $A<>A 2$ THEN 700 


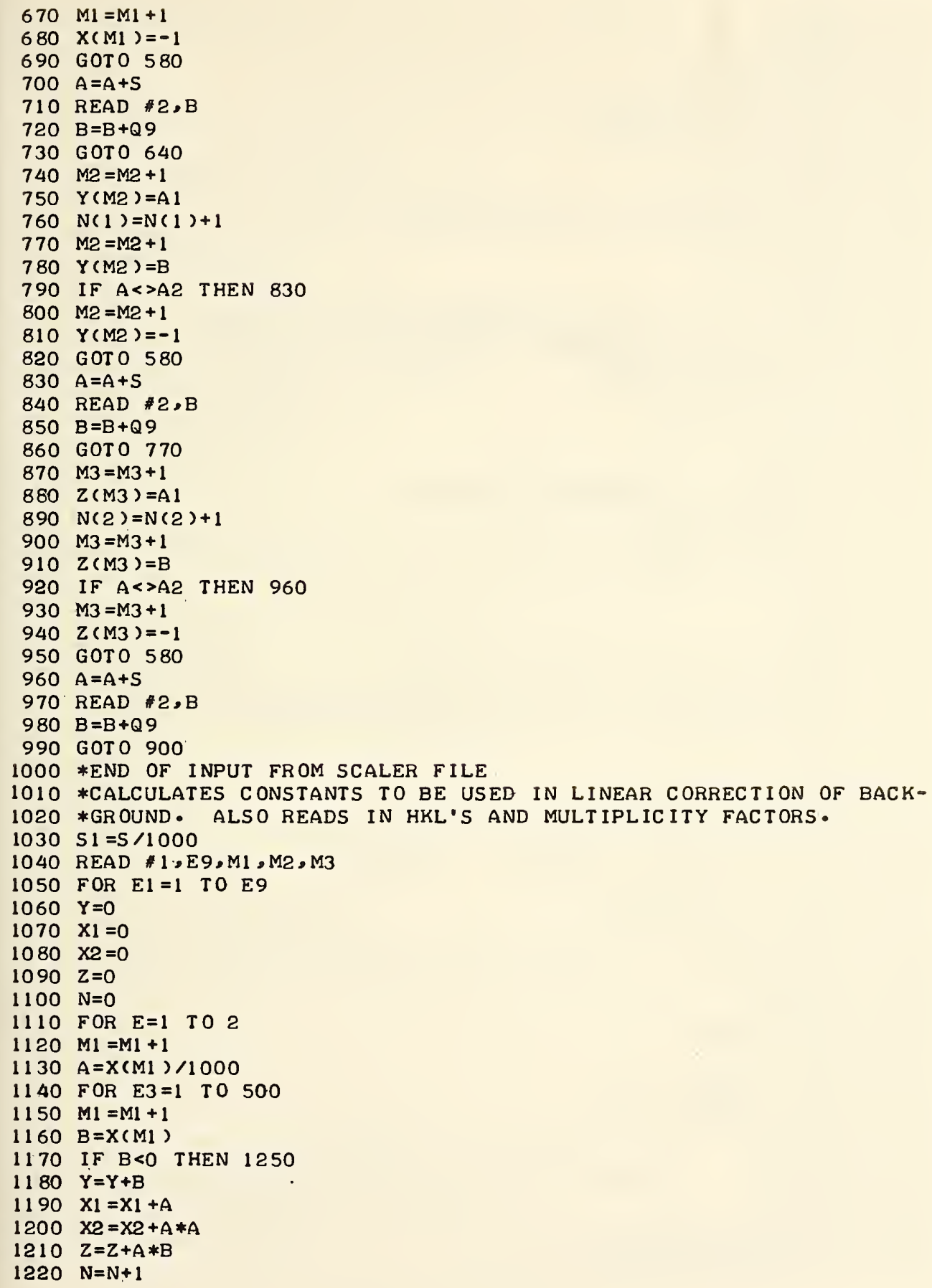




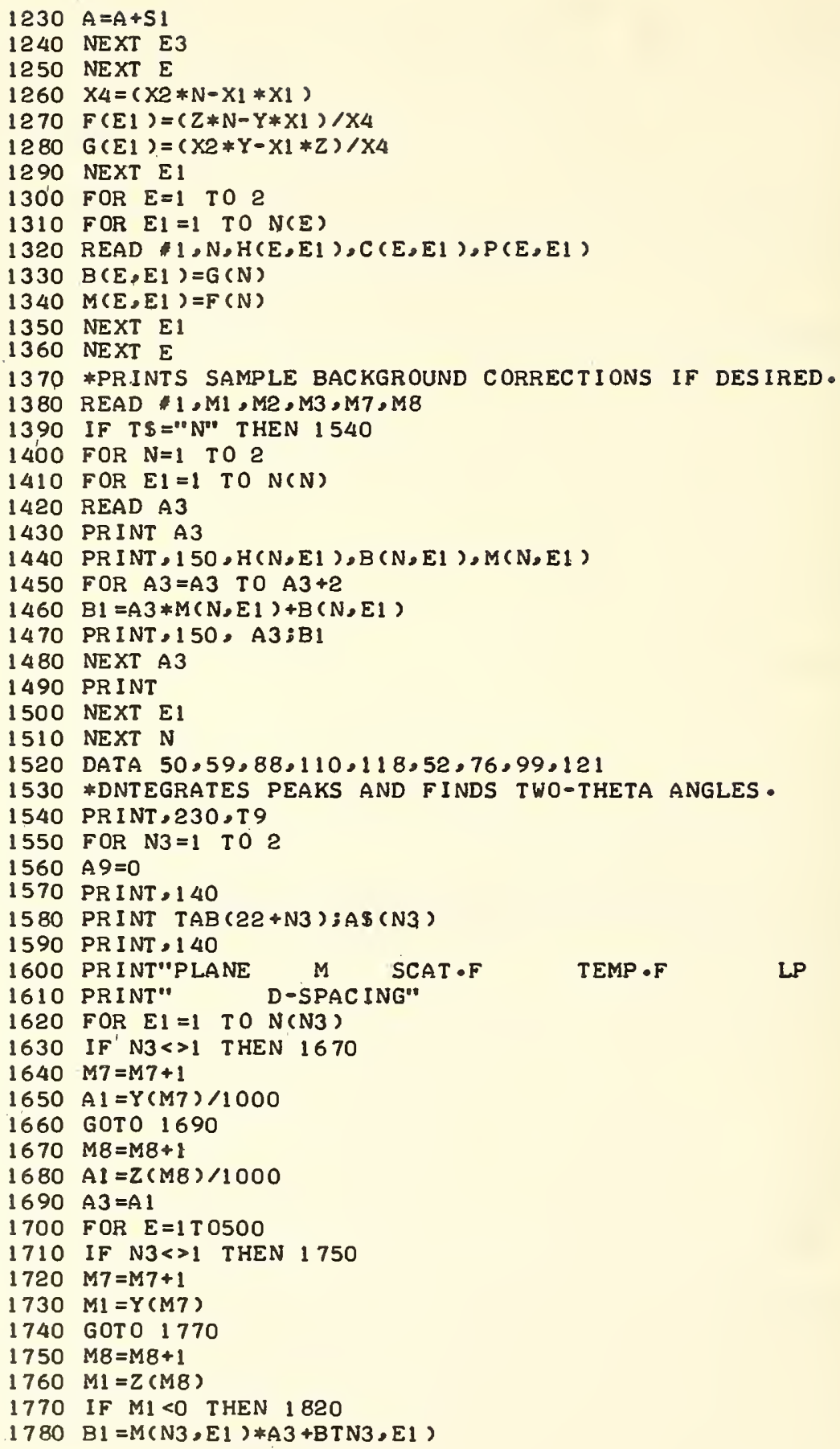




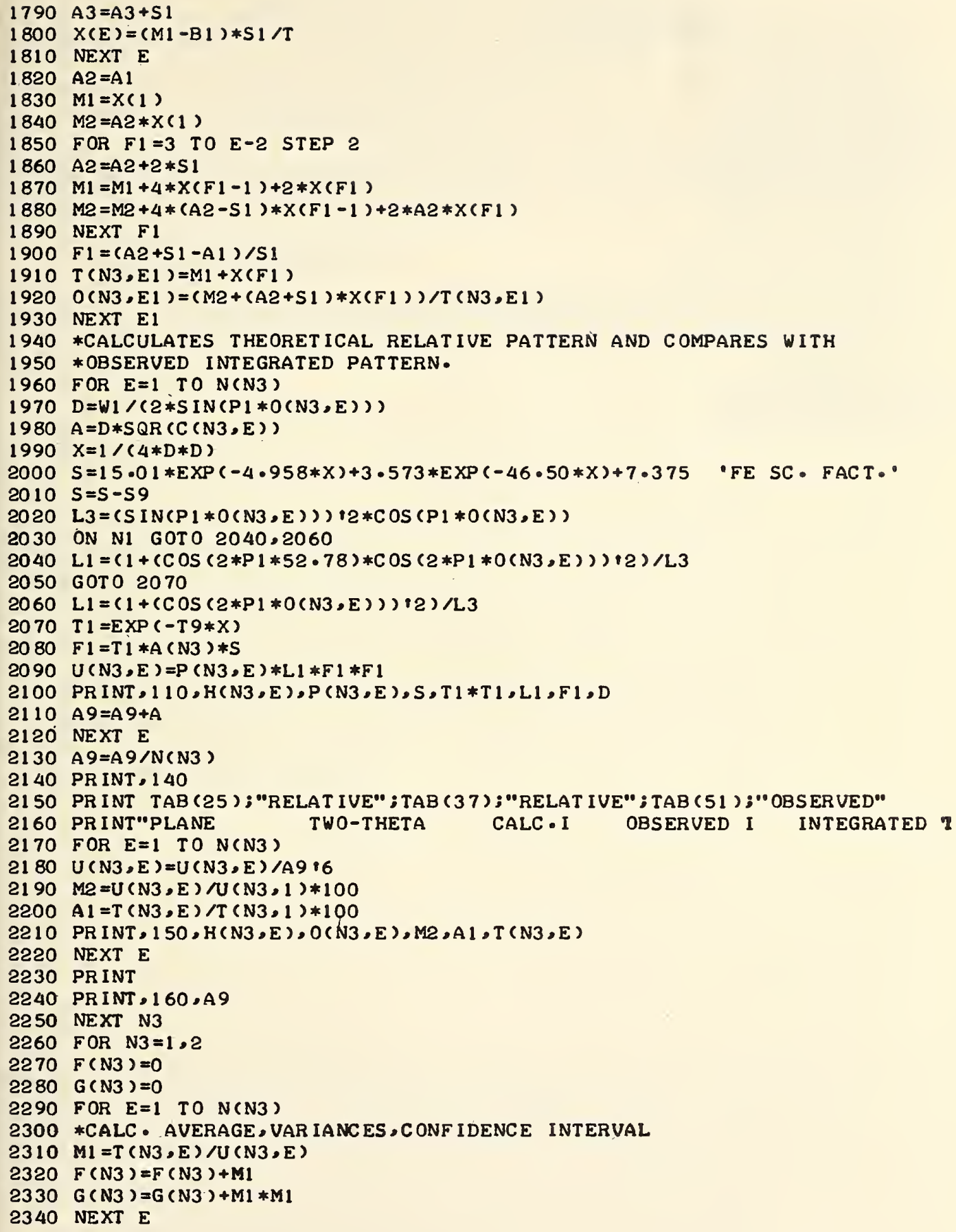




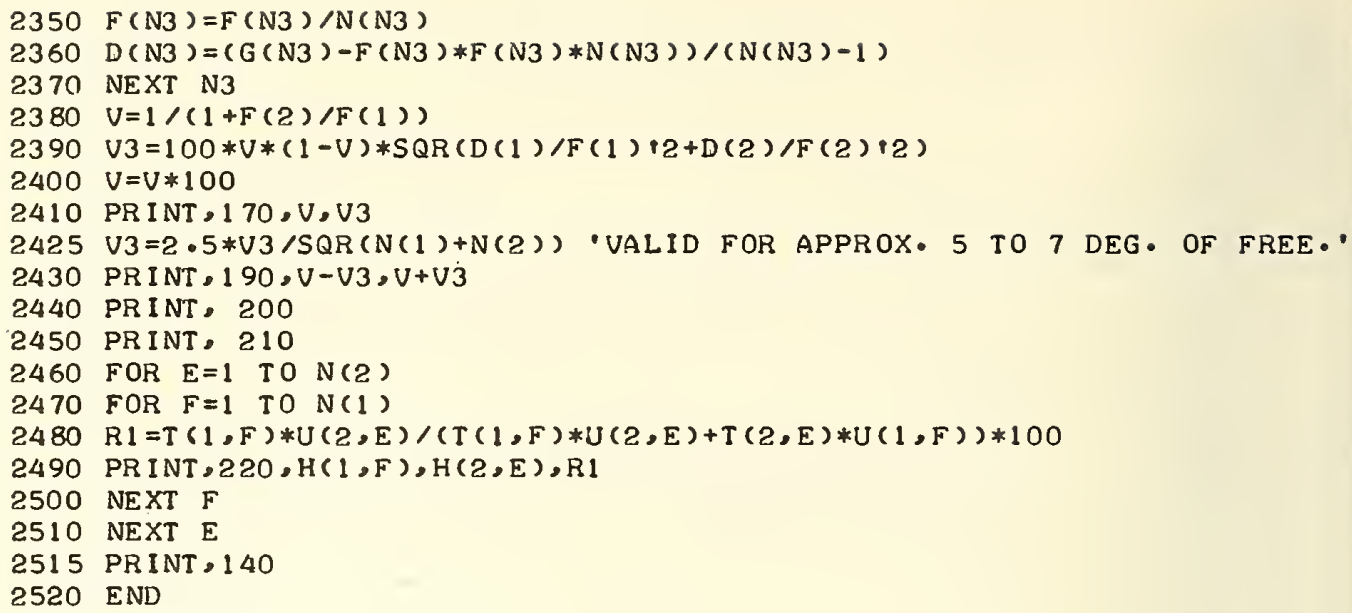


1. PUBLICATION OR REPORT NO. NBS-TN-709
2. Gov't Accession No.

4. TITLE AND SUBTITLE

An X-Ray Diffraction Method for Determining the Amount of Austenite in an Austenite-Ferrite Mixture

7. AUTHOR(S)

C. J. Bechtoldt

9. PERF ORMING ORGANIZATION NAME AND ADDRESS

NATIONAL BUREAU OF STANDARDS DEPARTMENT OF COMMERCE

WASHINGTON, D.C. 20234

12. Sponsoring Organization Name and Address

Same as No. 9.

13. Type of Report \& Period Covered

Final

14. Sponsoring Agency Code

15. SUPPLEMENTARY NOTES

16. ABSTRACT ( $\mathrm{A}$ 200-word or less factual summary of most significant information. If document includes a significant bibliography or literature survey, mention it here.)

A method for determining the relative phase volume of austenite in

an austenite-ferrite mixture is described in detail. Results obtained

by applying this method to an austenite-ferrite stainless steel

composite material are presented. The method can be extended to

other multi-phase materials.

17. KEY WORDS (Alphabetical order, separated by semicolons) Aus tenite; computer; ferrite; phase measurement; quantitative analysis; retained austenite; x-ray diffraction.

18. AVAILABILITY STATEMENT

X] UNLIMITED.

FOR OFFICIAL DISTRIBUTION. DO NOT RELEASE TO NTIS.
19. SECURITY CLASS (THIS REPORT)

UNCL ASSIF IED

20. SECURITY CLASS (THIS PAGE)
21. NO. OF PAGES

22. Price

$\$ .30$

UNCL ASSIFIED 



\section{PERIODICALS}

JOURNAL OF RESEARCH reports National Bureau of Standards research and development in physics, mathematics, chemistry, and engineering. Comprehensive scientific papers give complete details of the work, including laboratory data, experimental procedures, and theoretical and mathematical analyses. Illustrated with photographs, drawings, and charts.

Published in three sections, available separately:

\section{- Physics and Chemistry}

Papers of interest primarily to scientists working in these fields. This section covers a broad range of physical and chemical research, with major emphasis on standards of physical measurement, fundamental constants, and properties of matter. Issued six times a year. Annual subscription: Domestic, $\$ 9.50 ; \$ 2.25$ additional for foreign mailing.

\section{- Mathematical Sciences}

Studies and compilations designed mainly for the mathematician and theoretical physicist. Topics in mathematical statistics, theory of experiment design, numerical analysis, theoretical physics and chemisty, logical design and programming of computers and computer systems. Short numerical tables. Issued quarterly. Annual subscription: Domestic, \$5.00; $\$ 1.25$ additional for foreign mailing.

\section{- Engineering and Instrumentation}

Reporting results of interest chiefly to the engineer and the applied scientist. This section includes many of the new developments in instrumentation resulting from the Bureau's work in physical measurement, data processing, and development of test methods. It will also cover some of the work in acoustics, applied mechanics, building research, and cryogenic engineering. Issued quarterly. Annual subscription: Domestic, $\$ 5.00 ; \$ 1.25$ additional for foreign mailing.

\section{TECHNICAL NEWS BULLETIN}

The best single source of information concerning the Bureau's research, developmental, cooperative, and publication activities, this monthly publication is designed for the industry-oriented individual whose daily work involves intimate contact with science and technology-for engineers, chemists, physicists, research managers, product-development managers, and company executives. Annual subscription: Domestic, $\$ 3.00 ; \$ 1.00$ additional for foreign mailing.
NONPERIODICALS

Applied Mathematics Series. Mathematical tables, manuals, and studies.

Building Science Series. Research results, test methods, and performance criteria of building materials, components, systems, and structures.

Handbooks. Recommended codes of engineering and industrial practice (including safety codes) developed in cooperation with interested industries, professional organizations, and regulatory bodies.

Special Publications. Proceedings of NBS conferences, bibliographies, annual reports, wall charts, pamphlets, etc.

Monographs. Major contributions to the technical literature on various subjects related to the Bureau's scientific and technical activities.

\section{National Standard Reference Data Series.}

NSRDS provides quantitative data on the physical and chemical properties of materials, compiled from the world's literature and critically evaluated.

Product Standards. Provide requirements for sizes, types, quality, and methods for testing various industrial products. These standards are developed cooperatively with interested Government and industry groups and provide the basis for common understanding of product characteristics for both buyers and sellers. Their use is voluntary.

Technical Notes. This series consists of communications and reports (covering both other agency and NBS-sponsored work) of limited or transitory interest.

Federal Information Processing Standards Publications. This series is the official publication within the Federal Government for information on standards adopted and promulgated under the Public Law 89-306, and Bureau of the Budget Circular A-86 entitled, Standardization of Data Elements and Codes in Data Systems.

Consumer Inf ormation Series. Practical information, based on NBS research and experience, covering areas of interest to the consumer. Easily understandable language and illustrations provide useful background knowledge for shopping in today's technological marketplace.

NBS Special Publication 305, Supplement 1, Publications of the NBS, 1968-1969. When ordering, include Catalog No. C13.10:305. Price $\$ 4.50$; $\$ 1.25$ additional for foreign mailing. 
U.S. DEPARTMENT OF COMMERCE

National Bureau of Standards

Washington, D.C. 20234

OFFICIAL BUSINESS

Penalty for Private Use, $\$ 300$
POSTAGE AND FEES PAID U.S. DEPARTMENT OF COMMERCE

$$
\text { 函 }
$$

